\title{
ANALYSIS OF EFFECT OF PROFITABILITY, ASSETS STRUCTURE, SIZE OF COMPANIES, AND LIQUIDITY TO CAPITAL STRUCTURES IN MINING COMPANIES LISTED IN INDONESIA STOCK EXCHANGE PERIOD 2012 - 2015
}

\author{
Gatot Nazir Ahmad \\ Fakultas Ekonomi Universitas Negeri Jakarta \\ Email : ahmad72nazir@gmail.com \\ Ripa Lestari \\ Fakultas Ekonomi Universitas Negeri Jakarta \\ Email : rifaaga5@gmail.com \\ Sholatia Dalimunthe \\ Fakultas Ekonomi Universitas Negeri Jakarta \\ Email : tiadalimunthe@unj.ac.id
}

\begin{abstract}
The purpose of this study is to analyze the effect of profitability, structure assets, firm size and liquidity to the capital structure of mining companies listed on the Indonesia Stock Exchange for the period 2012-2015. Sampling technique using purposive sampling. Data analysis technique used in this research is panel data regression. The results showed that partially profitability had negative and significant effect on capital structure, asset structure had positive and significant effect to capital structure, firm size had positive and significant effect to capital structure, and liquidity had negative and significant effect to capital structure. Simultaneously profitability, asset structure, firm size and liquidity have a significant effect on capital structure.
\end{abstract}

Keywords: Profitability, Asset Structure, Company Size, Liquidity and Capital Structure 


\section{PENDAHULUAN}

Pertumbuhan kondisi ekonomi yang saat ini semakin meningkat menyebabkan ketatnya persaingan pada dunia usaha. Hal ini mendorong perusahaan untuk meningkatkan pertumbuhan kinerja perusahaan agar dapat bersaing. Untuk dapat bertahan dalam persaingan, perusahaan harus dapat meningkatkan laba perusahaan. Peningkatan laba perusahaan yang berkesinambungan dapat menghasilkan kinerja perusahaan yang baik, namun banyaknya hambatan yang dialami dalam menjalankan usaha salah satunya adalah mengenai masalah modal untuk mendanai aktivitas perusahaan.

Setiap perusahaan membutuhkan pendanaan untuk memenuhi modal dalam usaha bisnisnya, baik pendanaan secara internal maupun secara eksternal. Pendanaan yang diperoleh secara internal ialah pendanaan yang bersumber dari laba ditahan, sedangkan pendanaan yang diperoleh secara eksternal adalah pendanaan yang bersumber dari kreditur dan investor. Keputusan pendanaan yang diambil perusahaan tercermin dari struktur modal perusahaan.

Struktur modal perusahaan merupakan keseimbangan penggunaan pendanaan keuangan yang optimal dalam melakukan usaha. Struktur modal adalah kombinasi antara utang dan modal sendiri (Wiyono dan Kusuma, 2017:173). Modal yang bersumber dari utang akan menimbulkan beban bunga yang menjadi persyaratan dari pinjaman yang diberikan kreditur dan berdampak pada timbulnya risiko yang akan ditanggung oleh perusahaan berupa ketidakmampuan perusahaan dalam membayar kewajiban atas utang yang dipinjam dari pihak kreditur tersebut.

Jika perusahaan tidak menggunakan sumber dana yang berasal dari utang dalam struktur modal maka perusahaan tidak mencapai suatu nilai optimal yaitu dengan manfaat pajak yang diperoleh, karena dengan menggunakan utang maka perusahaan akan memperoleh manfaat dari perlindungan pajak akibat beban bunga yang timbul dari penggunaan utang tersebut.

Pecking order theory menyatakan bahwa perusahaan akan menentukan hierarki sumber dana yang paling disukai (Husnan dan Pudjiastuti, 2017:276). Hierarki sumber dana yang disukai adalah yang dibiayai dengan dana internal terlebih dahulu yaitu berupa laba ditahan dari perusahaan, kemudian baru diikuti oleh penerbitan hutang baru, dan akhirnya dengan penerbitan ekuitas baru. 
Struktur modal dihitung dengan cara membandingkan antara total utang perusahaan dengan total ekuitas yang dimiliki perusahaan dan diukur dengan menggunakan rasio Debt to Equity Ratio (DER). DER merupakan rasio yang digunakan untuk mengukur perbandingan antara total hutang dan total ekuitas (Hery, 2015:143). Jika DER semakin besar maka hal ini mencerminkan semakin besarnya risiko yang akan ditanggung perusahaan, dikarenakan modal yang bersumber dari pendanaan eksternal perusahaan berupa utang lebih tinggi dibandingkan dengan modal sendiri perusahaan tersebut.

Faktor yang dapat mempengaruhi struktur modal diantaranya adalah profitabilitas perusahaan. Profitabilitas dapat menggambarkan besarnya keuntungan yang diperoleh perusahaan atas kegiatan usaha yang dijalankan perusahaan. Profitabilitas adalah hasil akhir dari sejumlah kebijakan dan keputusan yang dilakukan oleh perusahaan (Brigham dan Houston, 2009:107). Tingginya tingkat profitabilitas yang dihasilkan perusahaan dapat dimanfaatkan sebagai sumber pendanaan, maka modal yang bersumber dari utang menjadi pilihan terakhir bagi perusahaan. Jika modal yang dihimpun dari utang sebagai pilihan terakhir akan dapat mempengaruhi tingkat DER yang rendah sebagai alat ukur struktur modal, sehingga tingginya tingkat profitabilitas perusahaan akan mempengaruhi struktur modal yaitu dengan menurunnya tingkat DER akibat rendahnya proporsi utang yang digunakan perusahaan sebagai sumber pendanaan untuk aktivitas operasi.

Berdasarkan penelitian yang dilakukan oleh Ajam (2015), Aprilia (2015), Bhawa dan Made (2015), Deitiana (2016), serta Dewi dan Ida (2014) bahwa profitabilitas berpengaruh negatif dan signifikan terhadap struktur modal, sedangkan penelitian yang dilakukan oleh Aurangzeb dan Anwar (2012) serta Adiyana dan Putu (2014) menyatakan bahwa profitabilitas berpengaruh positif signifikan terhadap struktur modal. Penelitian yang juga dilakukan oleh Dimitri dan Sumani (2013) menjelaskan bahwa profitabilitas berpengaruh negatif tidak signifikan terhadap struktur modal, sedangkan penelitian yang dilakukan oleh Putri (2012), Sansoethan dan Bambang (2016) menyatakan hasil penelitian bahwa profitabilitas berpengaruh positif tidak signifikan terhadap struktur modal. Hal ini dapat diartikan bahwa profitabilitas dapat dipergunakan sebagai alat ukur untuk menilai struktur modal dari perusahaan 
Struktur aktiva yang dimiliki perusahaan juga dapat berpengaruh terhadap struktur modal perusahaan. Struktur aktiva merupakan perbandingan antara aktiva tetap dengan total aktiva yang dimiliki oleh perusahaan. Perusahaan yang memiliki struktur aktiva yang besar akan dapat memberi sinyal positif berupa kepercayaan kepada kreditur, yaitu dalam hal kreditur dapat memberikan pinjaman utang kepada perusahaan yang memiliki struktur aktiva yang besar. Jika perusahaan tidak mampu untuk membayar kewajiban atas utang kepada kreditur, maka aktiva yang besar tersebut akan dapat dijadikan sebagai jaminan dari pinjaman utang yang telah dilakukan.

Berdasarkan penelitian yang dilakukan oleh Putri (2012), Cekrezi (2013), Dewi dan Ida (2014) serta juga Deitiana (2016) bahwa struktur aktiva berpengaruh positif signifikan terhadap struktur modal, sedangkan penelitian yang dilakukan oleh Aprilia (2015), Damayanti (2013), serta Sansoethan dan Bambang (2016) menjelaskan bahwa struktur aktiva berpengaruh negatif signifikan terhadap struktur modal. Penelitian yang juga dilakukan oleh Detiana (2016), Khaled dan Nurwati (2012), serta Sari dan Mulyo (2013) menyatakan bahwa struktur aktiva berpengaruh positif tidak signifikan terhadap struktur modal.

Ukuran perusahaan mencerminkan bagaimana besar kecilnya suatu aset dari perusahaan. Besar kecilnya suatu ukuran perusahaan akan mempengaruhi struktur modal dari perusahaan karena, semakin besar ukuran perusahaan maka perusahaan tersebut akan cenderung semakin besar dalam menggunakan utang sebagai modal yang digunakan perusahaan. Perusahaan yang berukuran besar umumnya mempunyai sinyal positif bagi kreditur karena dianggap memiliki risiko yang lebih kecil dibandingkan dengan perusahaan ukuran kecil.

Berdasarkan penelitian yang dilakukan oleh Ajam (2015), Putri (2012), Aprilia (2015), Dewi dan Ida (2014), serta juga Aurangzeb dan Anwar (2012) bahwa ukuran perusahaan berpengaruh positif signifikan terhadap struktur modal, sedangkan penelitian yang dilakukan oleh Dimitri dan Sumani (2013), Bhawa dan Made (2015) serta Sansoethan dan Bambang (2016) menjelaskan hasil penelitian bahwa ukuran perusahaan negatif tidak signifikan terhadap struktur modal. Penelitian yang juga dilakukan oleh Damayanti (2013) menyatakan bahwa ukuran perusahaan berpengaruh negatif signifikan terhadap struktur modal. Hal ini berarti 
bahwa ukuran perusahaan dapat dijadikan tolak ukur sebagai faktor yang mempengaruhi terhadap struktur modal.

Untuk mengukur suatu tingkat likuiditas dari perusahaan yaitu dengan membandingkan antara aktiva lancar perusahaan dengan kewajiban lancar perusahaan. Jika tingkat likuiditas perusahaan tinggi dapat diartikan bahwa perusahaan mempunyai kemampuan yang baik untuk membayar kewajiban jangka pendeknya. Kemampuan dari tingkat likuiditas yang tinggi maka dapat diartikan bahwa aktiva lancar lebih besar dibandingkan dengan kewajiban lancar yang diperoleh perusahaan sehingga berdampak dapat menurunkan penggunaan total utang perusahaan. Menurunnya total utang perusahaan akan mempengaruhi penggunaan pendanaan yang bersumber dari utang akan menjadi semakin rendah, sehingga perusahaan akan memanfaatkan penggunaan modal sendiri sebagai pendanaan untuk aktivitas perusahaan.

Berdasarkan penelitian Aprilia (2015), Sansoethan dan Bambang (2016), Cekrezi (2013), serta juga penelitian yang dilakukan oleh Sari dan Mulyo (2013) bahwa likuiditas berpengaruh negatif signifikan terhadap struktur modal, sedangkan penelitian yang dilakukan oleh Adiyana dan Putu (2014) bahwa likuiditas berpengaruh positif signifikan terhadap struktur modal. Penelitian yang juga dilakukan oleh Dimitri dan Sumani (2013) menyatakan hasil pengaruh penelitian bahwa likuiditas negatif tidak signifikan terhadap struktur modal.

\section{PERUMUSAN MASALAH}

Telah banyak dilakukan penelitian dalam menganalisis faktor yang mempengaruhi struktur modal, namun penelitian-penelitian tersebut belum memperoleh hasil yang selalu konsisten. Berdasarkan latar belakang masalah yang telah dipaparkan di atas, maka permasalahan yang dapat dirumuskan sebagai berikut:

1. Apakah profitabilitas berpengaruh terhadap struktur modal pada perusahaan pertambangan yang terdaftar di Bursa Efek Indonesia?

2. Apakah struktur aktiva berpengaruh terhadap struktur modal pada perusahaan pertambangan yang terdaftar di Bursa Efek Indonesia?

3. Apakah ukuran perusahaan berpengaruh terhadap struktur modal pada perusahaan pertambangan yang terdaftar di Bursa Efek Indoensia? 
4. Apakah likuiditas berpengaruh terhadap struktur modal pada perusahaan pertambangan yang terdaftar di Bursa Efek Indonesia?

5. Apakah profitabilitas, struktur aktiva, ukuran perusahaan, dan likuiditas secara simultan berpengaruh terhadap struktur modal pada perusahaan pertambangan yang terdaftar di Bursa Efek Idonesia?

\section{TUJUAN PENELITIAN}

Tujuan dari penelitian ini dilakukan adalah:

1. Untuk menguji secara empiris pengaruh profitabilitas terhadap struktur modal pada perusahaan pertambangan yang terdaftar di BEI

2. Untuk menguji secara empiris pengaruh struktur aktiva terhadap struktur modal pada perusahaan pertambangan yang terdaftar di BEI

3. Untuk menguji secara empiris pengaruh ukuran perusahaan terhadap struktur modal pada perusahaan pertambangan yang terdaftar di BEI

4. Untuk menguji secara empiris pengaruh likuiditas terhadap struktur modal pada perusahaan pertambangan yang terdaftar di BEI

5. Untuk menguji secara empiris pengaruh profitabilitas, struktur aktiva, ukuran perusahaan dan likuiditas secara simultan terhadap struktur modal pada perusahaan pertambangan yang terdaftar di BEI

\section{KAJIAN TEORITIK}

\section{Struktur Modal}

Menurut Sudana (2011:143) struktur modal berkaitan dengan perbelanjaan jangka panjang suatu perusahaan yang diukur dengan perbandingan utang jangka panjang dengan modal sendiri. Menurut Wiyono dan Kusuma (2017:173) struktur modal adalah kombinasi antara utang dan modal sendiri. Untuk mengetahui struktur modal yang dipilih perusahaan maka dapat dihitung dengan menggunakan rasio salah satunya adalah rasio utang terhadap modal sendiri atau DER (Debt to Equity Ratio) merupakan perbandingan antara hutang yang digunakan untuk membiayai aset perusahaan dengan total modal sendirinya. Menurut Hery (2015 : 169 ) rumus yang digunakan untuk menghitung rasio utang terhadap modal adalah sebagai berikut :

\section{Debt to Equity Ratio = Total Utang}

\section{Total Modal}




\section{PROFITABILITAS}

Profitabilitas adalah hasil akhir dari sejumlah kebijakan dan keputusan yang dilakukan oleh perusahaan (Brigham dan Houston, 2009:107). Hasil akhir dari sejumlah kebijakan dan keputusan tentunya hal ini bermaksud untuk dapat memperoleh laba. Dalam penelitian ini rasio yang digunakan untuk mengetahui tingkat profitabilitas adalah rasio return on asset (ROA) yang merupakan rasio yang menunjukkan seberapa besar kontribusi aset dalam menciptakan laba bersih. Untuk menghitung ROA dapat digunakan rumus sebagai berikut :

\section{ROA = Laba bersih}

\section{Total aset}

\section{STRUKTUR AKTIVA}

Struktur aktiva merupakan perbandingan antara total aktiva tetap dengan total aktiva yang dimiliki oleh perusahaan. Untuk mengukur besar kecilnya struktur aktiva maka dapat dihitung dalam bentuk rasio. Struktur aktiva dihitung dengan membandingkan total aktiva tetap terhadap total aktiva, yaitu:

\section{Struktur Aktiva = $\underline{\text { Total aktiva tetap }}$ \\ Total aktiva}

\section{UKURAN PERUSAHAAN}

Ukuran perusahaan mencerminkan bagaimana besar kecilnya suatu aset dari perusahaan. Besar kecilnya suatu ukuran perusahaan akan mempengaruhi kebutuhan struktur modalnya, karena dengan semakin besar ukuran perusahaan akan cenderung semakin besar dalam menggunakan utang untuk modal yang digunakan perusahaan. Kreditur menilai bahwa semakin besar ukuran perusahaan memiliki risiko yang lebih kecil dibandingkan dengan perusahaan yang mempunyai ukuran kecil. Untuk mengetahui ukuran perusahaan maka dapat dihitung dengan menggunakan rumus:

\section{Size $=$ Ln Total Aktiva}

\section{LIKUIDITAS}

Untuk mengukur tingkat likuiditas dari perusahaan yaitu dengan menggunakan rasio likuiditas. Hery (2015:142) menjelaskan bahwa rasio likuiditas merupakan rasio yang menggambarkan kemampuan perusahaan dalam memenuhi kewajiban jangka pendeknya yang segera jatuh tempo. Penelitian ini menggunakan current ratio unutk mengetahui seberapa besar kemampuan dari suatu perusahaan 
dalam memenuhi kewajiban jangka pendeknya. Dimana current dapat dihitung dengan menggunakan rumus sebagai berikut :

\section{Current ratio $=\underline{\text { Aktiva lancar }}$ \\ Utang lancar}

\begin{tabular}{|c|c|c|c|}
\hline Struktur Aktiva (X2) & $\mathrm{H} 1$ & \multirow{2}{*}{ H5 } & \multirow{3}{*}{$\begin{array}{c}\text { Struktur } \\
\text { Modal }\end{array}$} \\
\hline Profitabilitas (X1) & $\mathrm{H} 2$ & & \\
\hline Ukuran Perusahaan (X3) & H3 & & \\
\hline & $\mathrm{H} 4$ & & \\
\hline
\end{tabular}

Gambar 1. Model Penelitian

Sumber : Data diolah peneliti

\section{HIPOTESIS}

H1: Profitabilitas berpengaruh negatif signifikan terhadap struktur modal

H2: Struktur Aktiva berpengaruh positif signifikan terhadap struktur modal

H3: Ukuran Perusahaan berpengaruh positif signifikan terhadap struktur modal

H4: Likuiditas berpengaruh negatif signifikan terhadap struktur modal

H5: Profitabilitas, Struktur Aktiva,Ukuran Perusahaan, dan Likuiditas

berpengaruh signifikan terhadap struktur modal.

\section{METODE PENELITIAN}

Penelitian ini menggunakan metode penelitian asosiatif, yaitu metode penelitian yang digunakan untuk mengetahui hubungan dua variabel atau lebih pada suatu model penelitian. Dan juga model regresi yang digunakan dalam melakukan penelitian ini adalah dengan model regresi data panel (panel data regression analysis). Data panel merupakan gabungan antara deret waktu (time series) dan data cross section. Metode yang paling tepat untuk mengestimasi regresi data panel yaitu dengan langkah pertama melakukan uji chow terlebih dahulu, dan dilanjutkan dengan uji hausman. Penelitian ini menggunakan data operasional mulai dari tahun 2012 sampai dengan tahun 2015. 
Penelitian ini menggunakan populasi dari keseluruhan perusahaan pada sektor pertambangan yang terdaftar di Bursa Efek Indonesia (BEI). Perusahaan yang terdapat dalam sektor pertambangan adalah berjumlah 41 perusahaan. Dalam penelitian ini pemilihan sampel dilakukan berdasarkan purposive sampling yang bertujuan untuk mendapatkan sampel sesuai dengan kriteria yang ditentukan. Kriteria yang dipergunakan adalah perusahaan sektor pertambangan yang terdaftar di Bursa Efek Indonesia pada periode tahun 2012 sampai dengan tahun 2015 dan masih aktif, serta ketersediaan data laporan keuangan yang dipublikasikan di Bursa Efek Indonesia pada periode penelitian tahun 2012 sampai dengan tahun 2015. Berdasarkan kriteria tersebut maka sampel yang dapat digunakan dalam penelitian ini adalah berjumlah 27 perusahaan.

Teknik analisis data yang digunakan adalah Statistik Deskriptif memberikan gambaran atau deskripsi suatu data yang dilihat dari nilai rata-rata (mean), standar deviasi, varian, maksimum, minimum, sum, range, kurtosis dan skewness atau kemencengan distribusi (Ghozali, 2016:19). Analisis data dalam penelitian ini dengan menggunakan Eviews 9.4. Penelitian ini juga menggunakan uji hipotesis yaitu uji-t dan uji- F.

Asumsi klasik yang digunakan adalah uji multikolinearitas bertujuan untuk menguji apakah model regresi ditemukan adanya korelasi antara variabel bebas (independen). Model regresi yang baik seharusnya tidak terjadi korelasi di antara variabel independen (Ghozali, 2016:103). Multikolinearitas dilihat dengan mengukur nilai dari tolerance dan VIF (Variance Inflation Factor) yaitu menunjukkan setiap variabel independen manakah yang dijelaskan oleh variabel independen lainnya. Untuk menunjukkan adanya multikolinearitas dapat dilihat dengan nilai Tolerance $\leq 0,10$ atau sama dengan nilai VIF (Variance Inflation Factor $) \geq 10$, dimana VIF $=\frac{1}{1}$

\section{HASIL DAN PEMBAHASAN}

\section{Uji Multikolinieritas}

Uji multikolinearitas bertujuan untuk menguji apakah model regresi ditemukan adanya korelasi antara variabel bebas (independen). Nilai yang menunjukkan vatapya multikglinearitas adalah nifai Tolerance $\leq$ 0,10 atau sama Tabel 1 Hasil Uji Multikolinearitas

Coefficient Uncentered Centered


http://doi.org/10.21009/JRMSI

\begin{tabular}{cccc} 
Variable & Variance & VIF & VIF \\
\hline ROA & 0.056035 & 1.073256 & 1.050219 \\
\hline SA & 0.031293 & 4.071893 & 1.040550 \\
\hline UP & 0.000373 & 400.6045 & 1.074682 \\
\hline CR & 0.000107 & 1.790822 & 1.056881 \\
\hline C & 0.315070 & 404.7438 & NA
\end{tabular}

Sumber: Data diolah peneliti

Berdasarkan table 1 di atas diketahui bahwa setiap nilai VIF bernilai $<10$, sehingga dapat disimpulkan bahwa korelasi antara variabel bebas dalam penelitian ini tidak terjadi multikolinearitas.

\section{Hasil Uji Regresi}

Hasil uji regresi dengan menggunakan regresi data panel yaitu diperoleh persamaan estimasi model fixed effect, Persamaan regresi menunjukkan pengaruh profitabilitas (ROA), struktur aktiva, ukuran perusahaan dan likuiditas (CR) terhadap struktur modal yaitu sebagai berikut :

$\mathrm{DER}=-5,697971-0,496235 \mathrm{ROA}+0,574182 \mathrm{SA}+0,194639 \mathrm{UP}-0,080116 \mathrm{CR}$

Tabel 2. Model Fixed Effect

Dependent Variable: DER

Method: Pooled Least Squares

Date: 06/23/17 Time: 14:06

Sample: 14

Included observations: 4

Cross-sections included: 27

Total pool (balanced) observations: 108

\begin{tabular}{|c|c|c|c|c|}
\hline Variable & Coefficient & Std. Error & t-Statistic & Prob. \\
\hline $\mathrm{C}$ & -5.697971 & 1.562650 & -3.646351 & 0.0005 \\
\hline ROA & -0.496235 & 0.163391 & -3.037097 & 0.0033 \\
\hline SA & 0.574182 & 0.253947 & 2.261028 & 0.0266 \\
\hline UP & 0.194639 & 0.053620 & 3.629952 & 0.0005 \\
\hline CR & -0.080116 & 0.013852 & -5.783778 & 0.0000 \\
\hline R-squared & 0.891779 & \multicolumn{2}{|c|}{ Mean dependent var } & -0.115019 \\
\hline Adjusted R-squared & 0.849615 & \multicolumn{2}{|c|}{ S.D. dependent var } & 0.415572 \\
\hline S.E. of regression & 0.161157 & \multicolumn{2}{|c|}{ Akaike info criterion } & -0.577128 \\
\hline Sum squared resid & 1.999811 & \multicolumn{2}{|c|}{ Schwarz criterion } & 0.192743 \\
\hline Log likelihood & 62.16489 & \multicolumn{2}{|c|}{ Hannan-Quinn criter. } & -0.264973 \\
\hline F-statistic & 21.15023 & \multicolumn{2}{|c|}{ Durbin-Watson stat } & 1.912140 \\
\hline Prob(F-statistic) & 0.000000 & & & \\
\hline
\end{tabular}




\section{Uji-t (Parsial)}

\section{Pengaruh variabel ROA terhadap DER}

Berdasarkan Tabel 2, diketahui bahwa hasil perolehan coefficient return on assets sebesar -0,496235 dengan nilai probabilitas sebesar 0,0033 lebih kecil dari 0,05 hal ini berarti bahwa profitabilitas yang diproksikan dengan ROA berpengaruh negatif dan signifikan terhadap struktur modal yang diproksikan dengan DER. Semakin tinggi ROA maka dapat diartikan semakin baik kondisi suatu perusahaan sehingga perusahaan akan menggunakan return yang diperoleh tersebut untuk kebutuhan pendanaan dalam operasional perusahaan, hal ini akan berdampak pada penggunaan pendanaan dari eksternal perusahaan menjadi pilihan solusi yang terakhir. Hasil penelitian ini didukung oleh penelitian terdahulu yang dilakukan oleh Ajam (2015), Detiana (2016), Bhawa dan Made (2015) dan Damayanti (2013) menyatakan bahwa profitabilitas berpengaruh negatif signifikan terhadap struktur modal.

\section{Pengaruh variabel Struktur Aktiva terhadap Struktur Modal}

Coefficient struktur aktiva sebesar 0,574182 dengan nilai probabilitas sebesar 0,0266 lebih kecil dari 0,05 hal ini berarti bahwa struktur aktiva berpengaruh positif dan signifikan terhadap struktur modal (DER). Jika perusahaan memiliki struktur aktiva yang tinggi maka pihak keditur akan lebih tertarik untuk memberikan pinjaman sebagai pendanaan karena aktiva tetapnya dapat dijadikan jaminan jika perusahaan suatu saat mengalami gagal bayar. Perusahaan yang memiliki aktiva tetap yang besar sehingga dapat dijadikan jaminan, maka akan cenderung perusahaan tersebut akan menggunakan utang sebagai struktur modal dalam melaksanakan kegiatan usaha. Hasil penelitian ini didukung oleh penelitian terdahulu yang dilakukan oleh Dewi dan Ida (2014), Aurangzeb dan Anwar (2012), Cekrezi (2013) dan Putri (2012) yang menyatakan bahwa struktur aktiva berpengaruh positif signifikan terhadap struktur modal

\section{Pengaruh variabel Ukuran Perusahaan terhadap Struktur Modal}

Diketahui hasil perolehan coefficient ukuran perusahaan sebesar 0,194639 dengan nilai probabilitas sebesar 0,0005 lebih kecil dari 0,05 hal ini berarti bahwa ukuran perusahaan berpengaruh positif dan signifikan terhadap struktur modal (DER). Perusahaan besar akan cenderung menggunakan utang yang besar karena 
ukuran perusahaan dapat dijadikan jaminan untuk memperoleh utang. Hasil penelitian ini didukung oleh penelitian terdahulu yang dilakukan oleh Khaled dan Nurwati (2012), Munandar (2014), Adiyana dan Putu (2014), dan Ajam (2015) yang menyatakan bahwa ukuran perusahaan berpengaruh positif signifikan terhadap struktur modal.

\section{Pengaruh variabel Likuiditas terhadap Struktur Modal}

Diketahui hasil perolehan coefficient likuiditas sebesar -0,080116 dengan nilai probabilitas sebesar 0,0000 lebih kecil dari 0,05 hal ini berarti bahwa likuiditas berpengaruh negatif dan signifikan terhadap struktur modal (DER). Jika likuiditas perusahaan tinggi maka dapat diartikan bahwa aktiva lancar lebih besar dibandingkan dengan kewajiban lancar, sehingga perusahaan mampu untuk membayar kewajiban jangka pendeknya, yang berdampak pada menurunya tingkat total utang yang digunakan perusahaan sebagai pendanaan aktivitas perusahaan. Hasil penelitian ini didukung oleh penelitian terdahulu yang dilakukan oleh Sari dan Mulyo (2013), Sansoethan dan Bambang (2016), Cekrezi (2013), Aprilia (2015) yang menyatakan bahwa likuiditas berpengaruh negatif dan signifikan terhadap struktur modal.

\section{Uji-F (Simultan)}

Berdasarkan Tabel 2, diketahui nilai probabilitas F-statistik sebesar 0,0000 yang berarti lebih kecil dari 0,05 maka dapat disimpulkan bahwa secara simultan variabel Profitabilitas, Struktur Aktiva, Ukuran Perusahaan dan Likuiditas memiliki pengaruh yang signifikan terhadap struktur modal.

\section{Koefisien Determinasi}

Berdasarkan Tabel 2 diketahui nilai koefisien determinasi atau adjusted $R$-squared sebesar 0,849615 yang menunjukkan bahwa 84,96\% variabel dependen yaitu struktur modal (DER) yang digunakan dalam penelitian ini dapat dijelaskan oleh variabel profitabilitas, struktur aktiva, ukuran perusahaan dan likuiditas, sedangkan $15,04 \%$ sisanya dijelaskan oleh faktor lain yang tidak terdapat dalam variabel penelitian ini

\section{KESIMPULAN DAN SARAN}

\section{Kesimpulan}

Berdasarkan hasil penelitian yang telah dipaparkan sehingga diperoleh kesimpulan sebagai berikut : 
1. Profitabilitas yang diukur dengan menggunakan ROA berpengaruh negatif dan signifikan terhadap struktur modal (DER). Hasil penelitian ini menunjukkan bahwa semakin tinggi profitabilitas perusahaan maka tingkat struktur modal perusahaan akan menurun.

2. Struktur aktiva berpengaruh positif dan signifikan terhadap struktur modal. Hasil penelitian ini menunjukkan bahwa semakin tinggi struktur aktiva perusahaan maka akan meningkatkan struktur modal.

3. Ukuran perusahaan berpengaruh positif dan signifikan terhadap struktur modal. Hal ini menunjukkan bahwa semakin tinggi ukuran perusahaan maka stuktur modal akan meningkat.

4. Likuiditas yang diukur dengan menggunakan CR berpengaruh negatif dan signifikan terhadap struktur modal (DER). Hasil penelitian ini menunjukkan bahwa semakin tinggi likuiditas perusahaan maka tingkat struktur modal perusahaan akan menurun.

5. Secara simultan variabel profitabilitas, struktur aktiva, ukuran perusahaan dan likuiditas berpengaruh signifikan terhadap struktur modal

\section{Saran}

Berdasarkan hasil penelitian yang telah dilakukan, maka saran yang dapat diberikan peneliti adalah sebagai berikut :

1. Peneliti selanjutnya yang melakukan penelitian sejenis sebaiknya menambahkan variabel lain yang tidak digunakan dalam penelitian ini, serta menambah jumlah sampel dengan menggunakan perusahaan sektor lain yang terdaftar di BEI dan memperpanjang periode penelitian, sehingga dapat memberikan hasil penelitian yang lebih bervariasi terhadap pengaruh struktur modal.

2. Perusahaan sebaiknya memperhatikan penggunaan proporsi utang dengan modal sendiri sehingga dapat dengan tepat dalam mengambil keputusan terkait penggunaan struktur modal yang optimal, serta memperhatikan keempat variabel yang secara signifikan berpengaruh terhadap struktur modal sehingga dapat meminimal risiko dan memaksimalkan laba yang diperoleh. 
3. Investor sebaiknya dalam mengambil keputusan investasi dapat memperhatikan struktur modal optimal yang digunakan untuk pendanaan aktivitas perusahaan, hal ini karena struktur modal yang optimal dapat meminimalkan risiko dan juga dapat memaksimalkan laba sehingga investor dapat memperoleh deviden.

\section{DAFTAR PUSTAKA}

Adiyana, Ida Bagus G.N.S dan Putu Agus A. (2014). Pengaruh Ukuran Perusahaan, Risiko Bisnis, Pertumbuhan Aset, Profitabilitas Dan Tingkat Likuiditas Pada Struktur Modal, E-Jurnal Manajemen Universitas Udayana, Vol.10, No.1, 14-30.

Ajam, Al Muktadirsyah. (2015). Pengaruh Ukuran Perusahaan dan Profitabilitas Terhadap Struktur Modal Pada Perusahaan Manufaktur Yang Terdaftar di Bursa Efek Indonesia, Skripsi, Fakultas Ekonomi dan Bisnis Universitas Sumatera Utara

Aprilia, Resti Dara Ayu. (2015). Pengaruh stuktur aktiva, likuiditas, ukuran perusahaan dan profitabilitas terhadap struktur modal pada perusahaan manufaktur yang terdaftar di Bursa Efek Indonesia, Skripsi, Fakultas Ekonomi Universitas Negeri Yogyakarta

Aurangzeb dan Anwar ul Haq. (2012). Determinants of Capital Structure: A Case From Textile Industry of Pakistan, International Journal of Academic Research in Business and Social Sciences, Vol. 2, No. 4

Bhawa, Ida Bagus M.D dan Made. R. Dewi S. (2015). Pengaruh Ukuran Perusahaan, Likuiditas, Profitabilitas, dan Risiko Bisnis Terhadap Struktur Modal Perusahaan Farmasi, E-Jurnal Manajemen Unud, Vol.4, No,7, 19491966

Brigham dan Houston. (2009). Fundamentals of Financial Management, Jakarta: Salemba Empat

Cekrezi, Anila. (2013). Impact of Firm Specific Factors on Capital Structure Decision: An Empirical Study of Albanian Firms, European Journal of Sustainable Development, Vol. 2, No. 4, 13-148

Damayanti. (2013). Pengaruh Struktur Aktiva, Ukuran Perusahaan, Peluang Pertumbuhan dan Profitabilitas Terhadap Struktur Modal, Jurnal Perspektif Bisnis, Vol. 1, No. 1 
Deitiana, Tita. (2016). The Effect of Firm Size, Profitability, Tangibility, NonDebt Tax Shield and Growth to Capital Structure on Banking Firms Listed in Indonesia Stock Exchange From 2007 - 2012, South East Asia Journal of Contemorary Business, Economics and Law, Vol. 10, No. 1

Dewi, Ni Kadek S.M dan Ida Bagus Badjra. (2014). Pengaruh Likuiditas, Profitabilitas, Tangibility Assets, Ukuran Perusahaan Dan Pajak Terhadap Struktur Modal, E-Jurnal Manajemen Universitas Udayana, Vol. 3, No. 10

Dimitri, Michael dan Sumani. (2013). Analisis Pengaruh Likuiditas, Profitabilitas, Ukuran, Usia dan Pertumbuhan Perusahaan Terhadap Struktur Modal, Jurnal Manajemen, Vol. 1, No.1

Ghozali, Imam. (2016). Aplikasi Analisis Multivariete dengan Program IBM SPSS 23, Semarang : BP UNDIP

Hery. (2015). Analisis Kinerja Manajemen, Jakarta : Grasindo

Husnan, Suad dan Enny Pudjiastuti. (2017). Dasar-dasar Manajemen Keuangan,Cetakan Keenam Yogyakarta : UPP STIM YKPN

Khaled, BA-ABBAD dan Nurwati Ashikkin A.Z. (2012). The Determinants of Capital Structure of Qatari Listed Companies, International Journal of Academic Research in Accounting, Finance and Management Sciences, Vol.2, No. 2

Margaretha, Farah. (2011). Manajemen Keuangan, Jakarta : Salemba Empat.

Munandar, Agus. (2014). Effect of Size, Profitability, and Growth Rate Towards Capital Structure, Jurnal Dinamika Manajemen, Vol. 2, No. 3, 2014.

Putri, Meidera Elsa Dwi.(2012). Pengaruh Profitabilitas, Struktur Aktiva dan Ukuran Perusahaan Terhadap Struktur Modal pada Perusahaan Manufaktur Sektor Industri Makanan dan Minuman yang Terdaftar di Bursa Efek Indonesia (BEI), Jurnal Manajemen, Vol.1, No.1

Sansoethan, Dithya Kusuma dan Bambang Suryono. (2016). Faktor-faktor Yang Mempengaruhi Struktur Modal Pada Perusahaan Makanan Dan Minuman, Jurnal Ilmu dan Riset Akuntansi, Vol. 5, No.1

Sari, Devi Verena dan A. Mulyo Haryanto. (2013). Pengaruh Profitabilitas, Pertumbuhan Aset, Ukuran Perusahaan, Struktur Aktiva Dan Likuiditas Terhadap Struktur Modal Pada Perusahaan Manufaktur di Bursa Efek Indonesia Tahun 2008 - 2010, Diponegoro Journal Of Management, Vol. 2, No. 3 
Sudana, I Made. (2011). Manajamen Keuangan Perusahaan Teori \& Praktik,Surabaya : Erlangga

Widyastuti, Umi. (2015). Dasar-dasar Manajemen Keuangan, Jakarta : LPP UNJ

Wiyono, Gendro dan Hadri Kusuma. (2017). Manajemen Keuangan Lanjutan, Cetakan Pertama Yogyakarta : UPP STIM Y 